\title{
POLA AKTIVITAS IBU RUMAH TANGGA TERHADAP PEMANFAATAN RUANG TERBUKA DI RUMAH SUSUN
}

\author{
Yosica Mariana \\ Architecture Department, Faculty of Engineering, Binus University \\ Jl. K.H. Syahdan No. 9, Palmerah, Jakarta Barat 11480 \\ mariana_yosica@binus.ac.id
}

\begin{abstract}
In flat environments, housewives are most found staying throughout the day. They use existing open spaces in housing project to interact with other residents. To find out, discover and analyze the correlation between the pattern of open space utilization and the pattern of activity of housewives at flats, this research was conducted using descriptive analysis method bases on case studies on some flats in urban areas, namely Kebon Kacang Flat (KK), Kemayoran Flat (K), Taman Surya Flat (TS) and Pasar Jumat Flat (PJ). Subjects were housewives (residents of the flats); sampling is taken by stratified random sampling. The survey was conducted by interview to obtain data on activity patterns of the mother. Subsequently, observation was conducted to get an overview of the activity patterns of mothers and use of open space including non-physical and physical data of these open spaces. The implementation was done in three stages: preparation (literature study and data collection by remote sensing), interpretation, field test and re-interpretation (width, location, quality of open spaces and activities, professions of women at these locations), and result presentation.
\end{abstract}

Keywords: housewives, flats, open spaces, interaction

\begin{abstract}
ABSTRAK
Ibu rumah tangga merupakan kelompok yang paling sering berada di lingkungan rumah susun sepanjang hari. Mereka menggunakan ruang terbuka yang ada di rumah susun untuk berinteraksi dengan penghuni lain. Untuk mengetahui, menemukan dan menganalisis hubungan (korelasi) antara pola pemanfaatan ruang terbuka dengan pola aktivitas kaum ibu rumah tangga penghuni rumah susun, penelitian ini dilakukan menggunakan metode deskriptif analisis dari studi kasus pada beberapa rumah susun di daerah perkotaan, yaitu Rumah Susun Kebon Kacang (KK), Kemayoran (K), Taman Surya (TS) dan Pasar Jumat (PJ). Subyek penelitian adalah kaum ibu penghuni rumah susun tersebut; teknik sampling menggunakan stratified random sampling. Survey dilakukan dengan teknik wawancara untuk mendapatkan data-data mengenai pola aktivitas kaum ibu. Selanjutnya dilakukan pengamatan untuk mendapatkan gambaran pola aktivitas kaum ibu dan pemanfaatan ruang terbuka berikut data fisik dan data non fisik dari ruang terbuka tersebut. Pelaksanaan ini dilakukan dalam tiga tahap, yaitu tahap persiapan (studi pustaka dan pengumpulan data dengan penginderaan jauh), tahap interprestasi, uji lapangan dan interprestasi ulang (luas, lokasi, kualitas ruang terbuka dan aktivitas, pekerjaan kaum ibu di lokasi tersebut) dan tahap penyajian hasil.
\end{abstract}

Kata kunci: ibu rumah tangga, rumah susun, ruang terbuka, interaksi 


\section{PENDAHULUAN}

Ketersediaan ruang terbuka kota sangat penting dalam perencanaan sebuah kota. Tetapi seiring dengan perkembangan dan pertumbuhan jumlah penduduk kota, ketersediaan lahan untuk pemukiman masyarakat semakin sempit, sehingga penyediaan ruang terbuka dalam suatu lingkungan terkadang diabaikan. Dengan kepadatan penduduk yang meningkat dan semakin banyak dibangunnya daerah pemukiman yang disertai dengan sarana dan prasarana perkotaan tersebut, mengakibatkan berkurangnya ruang terbuka bagi masyarakat di dalam suatu lingkungan tertentu yang berfungsi sebagai wadah interaksi sosial, maupun ruang hijau terbuka yang berfungsi ekologis.

Menurut Supriyatno (2009), ada beberapa manfaat ruang terbuka yang ditinjau dari beberapa aspek, yaitu aspek ekologis, sosial/budaya, arsitektur dan ekonomi. Secara ekologis, ruang terbuka yang hijau dapat menurunkan temperatur kota, mengurangi polusi udara, mencegah banjir dan meningkatkan kualitas air tanah. Secara sosial budaya, keberadaan ruang terbuka dapat memberikan fungsi sebagai ruang berinteraksi, sarana rekreasi dan sebagai 'tanda' kota berbudaya. Wujudnya seperti taman kota, lapangan olah raga atau makam. Secara arsitektur, ruang terbuka dapat meningkatkan keindahan dan kenyamanan kota melalui keberadaan taman-taman kota, jalur-jalur hijau dan jalan-jalan kota. Sementara ditinjau dari sisi ekonomi, ruang terbuka hijau yang dikelola dengan baik dan menarik akan mengundang penghuni kota hadir berekreasi dan membangkitkan sektor ekonomi di sekitarnya seperti jasa parkir, warung, tempat makan dan sebagainya.

Batasan ruang terbuka secara makro diciptakan oleh tatanan bangunan, seperti ruang horizontal dibatasi oleh dinding dan ruang vertikal yang dibatasi kanopi. Ruang terbuka dalam suatu hunian, menurut Roger Trancik dalam teorinya yaitu Tata Pola Ruang Kota (Figure Ground Theory), didasari atas pemahaman bentuk ruang yang diawali dengan analisis hubungan antara massa bangunan dan ruang terbuka itu sendiri (solid dan void). Ruang umum terbuka adalah ruang umum di luar bangunan yang dapat digunakan oleh publik (setiap orang) dan memberi kesempatan untuk bermacammacam kegiatan (Rustam Hakim, 1991). Ruang terbuka itu sendiri dibagi menjadi dua macam yaitu hard space (perkerasan, plaza, alun-alun dan lainnya) dan soft space (jalur hijau, air mancur, kolam, taman dan lainnya).

Interaksi sosial adalah hubungan sosial yang dinamis antara orang perseorangan dan orang perseorangan, antara perseorangan dengan kelompok, serta antara kelompok dengan kelompok (Kamus Besar Bahasa Indonesia, 2008). Interaksi sosial merupakan suatu hubungan yang terjalin antara dua individu atau lebih, dimana salah satu individu dapat mempengaruhi, mengubah, atau memperbaiki individu yang lain atau sebaliknya. Hal-hal yang terkait dalam interaksi sosial antara lain: komunikasi, norma dan nilai sosial, prasangka dan konflik sosial, serta pergaulan dan persahabatan, salah satu contoh: perkumpulan wanita. Perkumpulan wanita ini merupakan realita dalam berinteraksi sosial antar sesama. Komunikasi sosial berhubungan dengan perilaku seorang ibu dan kepuasan terpenuhinya kebutuhan ibu tersebut berinteraksi dengan ibu yang lainnya. Perkumpulan ibu-ibu ini dapat dilakukan dimana saja dan kapan saja sebagai contoh nyata dari adanya interaksi sosial ini. Wanita merupakan bagian dari masyarakat pada satu lingkungan binaan turut berperan dalam menentukan keberhasilan penyediaan ruang terbuka dan pemanfaatannya, karena kaum wanita lebih peduli terhadap lingkungan dibandingkan kaum pria (Wilson dalam Miles et al., 2000).

Menurut Undang-Undang No. 20 tahun 2011 mengenai rumah susun, pembangunan rumah susun diarahkan untuk memenuhi kebutuhan perumahan yang layak dalam lingkungan yang sehat, secara adil dan merata serta mampu mencerminkan kehidupan masyarakat yang berkepribadian Indonesia, dan untuk mewujudkan pemukiman yang serasi dan seimbang, sesuai dengan pola tata ruang kota dan tata daerah serta tata guna tanah yang berdaya guna dan berhasil guna. 
Selain itu hak milik rumah susun, meliputi hak bersama atas bagian-bagian dari bangunan rumah susun, hak bersama atas benda-benda dan hak bersama atas tanah yang semuanya merupakan satu kesatuan hak yang secara fungsional tidak terpisahkan (UU No. 20 tahun 2011).

Manusia biasanya cenderung untuk memilih suatu lingkungan yang sesuai dan memuaskan bagi dirinya, sehingga dapat bermukim dengan baik, sambil mempersiapkan masa depan keluarga. Adanya berbagai pilihan terhadap ruang dan komponennya, menyebabkan suatu perilaku tertentu, yang sering tidak terwadah sehingga tidak terdapat kesesuaian, sehingga timbul suasana yang tidak diinginkan bersama. Terkait dengan penghuni dalam rumah susun, keputusan tindakan yang dipilih oleh warga, umumnya muncul secara spontan dan merupakan gambaran dari karakternya, seperti realisasi bersama dalam ruang yang dianggap cocok, sehingga dapat menimbulkan permasalahan lain (suasana bising dan tidak tertib). Kondisi ini masih dapat diterima oleh penghuni dalam batas-batas tertentu (sesuai dengan tingkatan toleransi yang diberikan oleh masyarakat golongan berpenghasilan rendah). Hal ini memperkuat teori dari Abraham Maslow, bahwa manusia merupakan mahkluk yang paling mudah beradaptasi terhadap lingkungan sekitarnya, dengan cara mengubah dan membentuk lingkungan tersebut, sehingga sesuai dengan karakternya. Adaptasi merupakan keadaan seimbang antara daya atur (akomodasi) dan daya lebur (asimilasi). Jadi, antara lingkungan dan manusia akan selalu saling mengimbangi satu sama lain, sehingga karakter penghuni dapat memasuki lingkungan tersebut, sehingga dapat memperkecil kendala yang timbul, yang mungkin merugikan diri sendiri maupun orang lain. Ruang bersama adalah suatu wadah yang dapat menampung berbagai kegiatan kebersamaan masyarakat (positif atau negatif) di dalam memenuhi kebutuhan ekonomi, budaya dan sosial warganya.

Terkait dengan kehidupan penghuni rumah susun khusus masyarakat yang berpenghasilan rendah, ruang bersama berfungsi sebagai wadah temu warga - dimana proses sosialisasi/interaksi antara warga dapat berlangsung, transaksi ekonomi, menempa moral, dan memperluas wawasan. Terkait dengan karakter penghuni berpenghasilan rendah, dilihat dari segi sosial: mereka senang berkumpul (penuh kebersamaan), kurang menyukai hal yang bersifat formil, memiliki kecenderungan okupasi pada lahan yang ‘dianggap’ milik bersama/tidak dimiliki siapapun. Dari segi ekonomi, mereka dari golongan sederhana. Umumnya, kaum ibu dari kalangan ini memiliki fungsi ganda (sebagai pencari nafkah tambahan sekaligus mengatur kehidupan keluarga). Dari segi budaya, mereka berasal dari berbagai latar budaya.

Keberadaan ruang terbuka pada lingkungan rumah susun, diharapkan dapat membantu meningkatkan kualitas masyarakat yang menghuni rumah susun tersebut. Oleh karena itu, maka dilakukan penelitian untuk mengetahui dan mengungkapkan pola kegiatan kaum ibu dalam pemanfaatan ruang terbuka yang berada pada lingkungannya tersebut. Sehingga dapat diwujudkan perencanaan ruang terbuka yang keberadaannya dapat dimanfaatkan secara maksimal oleh penghuninya. Keberadaan ruang terbuka ini, diharapkan dapat memberikan kenikmatan bagi pemakainya dan harus mudah diketahui keberadaannya.

\section{METODE}

Dalam hal ini, penelitian menggunakan metode deskriptif analisis yang bertujuan untuk mengetahui, menemukan dan menganalisis hubungan (korelasi) antara pola pemanfaatan ruang terbuka dengan pola aktivitas kaum ibu (ibu rumah tangga) penghuni rumah susun tersebut. Pemilihan subyek dan lokasi penelitian dilakukan dengan menggunakan studi kasus pada beberapa rumah susun yang memiliki kategori yaitu berada di daerah perkotaan dan cukup lama dihuni, dimana penelitian memilih lokasi penelitian yaitu Rumah Susun Kebon Kacang (KK), Kemayoran (K), Taman Surya (TS) dan Pasar Jumat (PJ). 
Pengumpulan data-data dilakukan dengan survei dan pengamatan pada lokasi penelitian. Metode pengamatan dilakukan untuk mendapatkan gambaran pola aktivitas kaum ibu dan pemanfaatan ruang terbuka berikut data fisik dan data non fisik dari ruang terbuka tersebut. Metode ini dilakukan melalui interprestasi dan penginderaan jauh. Pelaksanaan ini dilakukan dalam tiga tahapanya itu tahap persiapan (studi pustaka dan pengumpulan data dengan penginderaan jauh), tahap interprestasi, uji lapangan dan interprestasi ulang (luas, lokasi, kualitas ruang terbuka dan aktivitas, pekerjaan kaum ibu yang ada di lokasi tersebut) dan tahap penyajian hasil. Sedangkan metode survey dilakukan untuk mendapatkan data-data mengenai pola aktivitas kaum ibu, yaitu dengan teknik wawancara. Populasi yang diambil sebagai subyek penelitian adalah kaum ibu penghuni rumah susun tersebut, teknik sampling yang digunakan adalah stratified random sampling, teknik ini banyak di gunakan untuk mempelajari karakteristik yang berbeda dan mengurangi pengaruh faktor heterogen. Dalam teknik ini dilakukan pembagian elemen-elemen populasi ke dalam strata, untuk selanjutnya dari masing-masing strata dipilih sampel secara random (acak) sesuai proporsinya.

\section{HASIL DAN PEMBAHASAN}

Gambar 1 - 3 di bawah ini merupakan hasil pengamatan yang dilakukan terhadap kondisi ruang terbuka dan kegiatan kaum ibu di rumah susun lokasi penelitian.
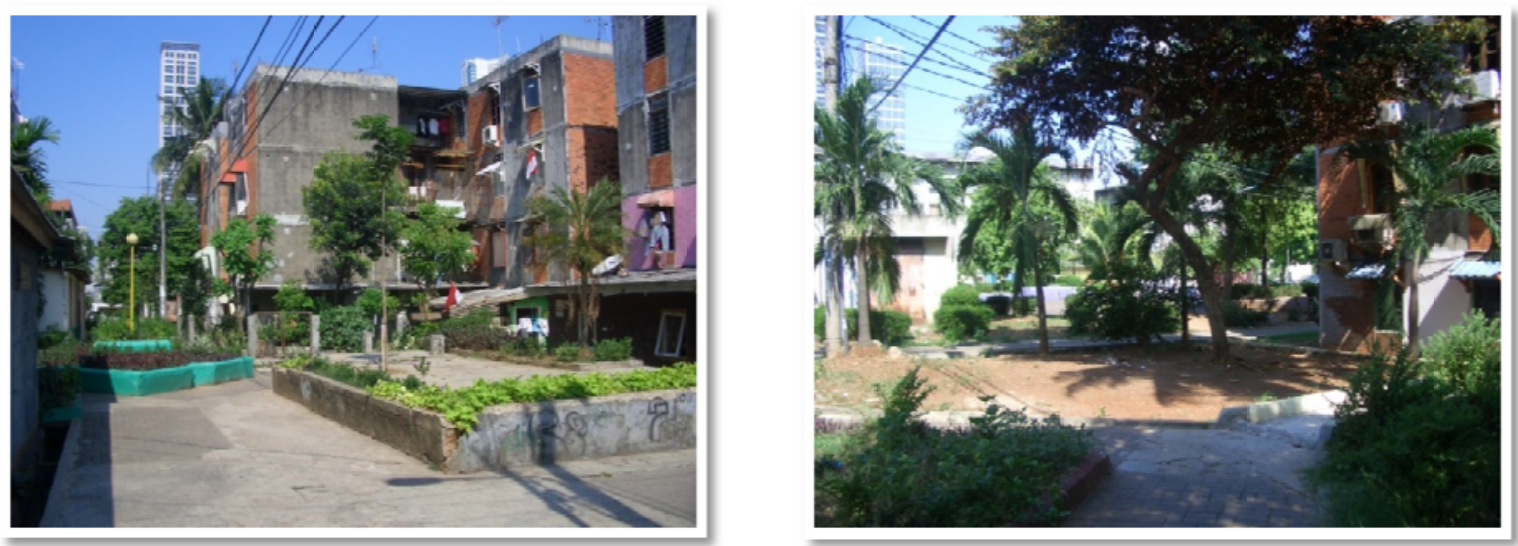

Gambar 1. Kondisi ruang terbuka di Rumah Susun Kebon Kacang. (Sumber): Dokumentasi Penelitian Arsitektur Binus
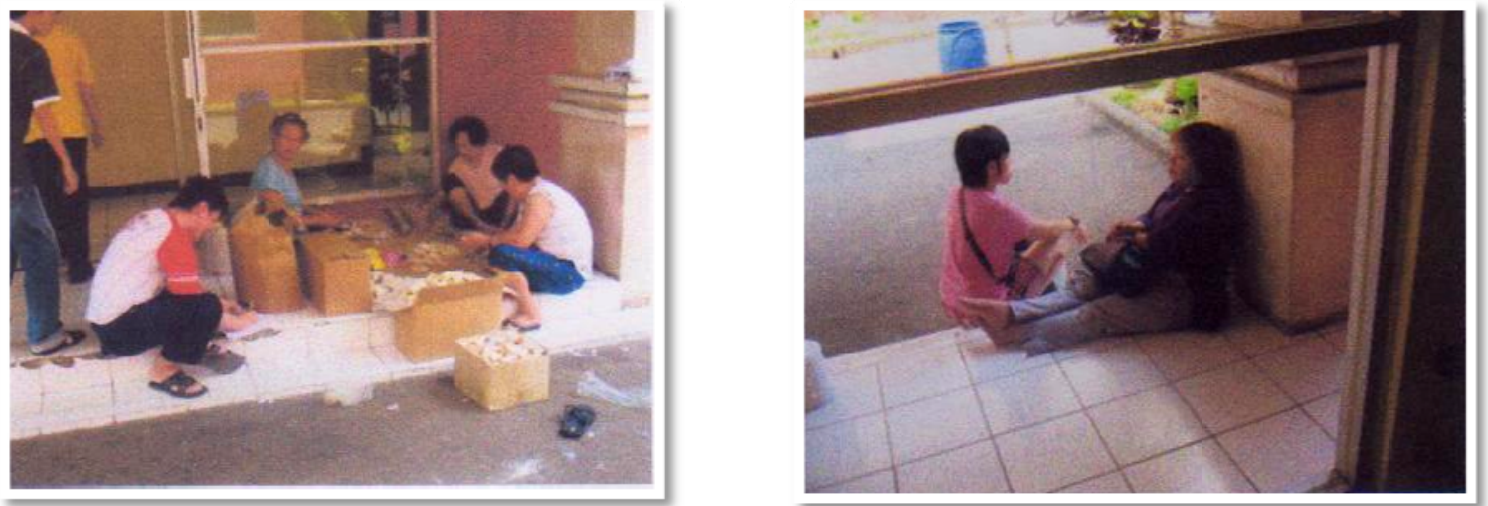

Gambar 2. Kegiatan kaum ibu di Rumah Susun Taman Surya. (Sumber: Dokumentasi Penelitian Arsitektur Binus) 

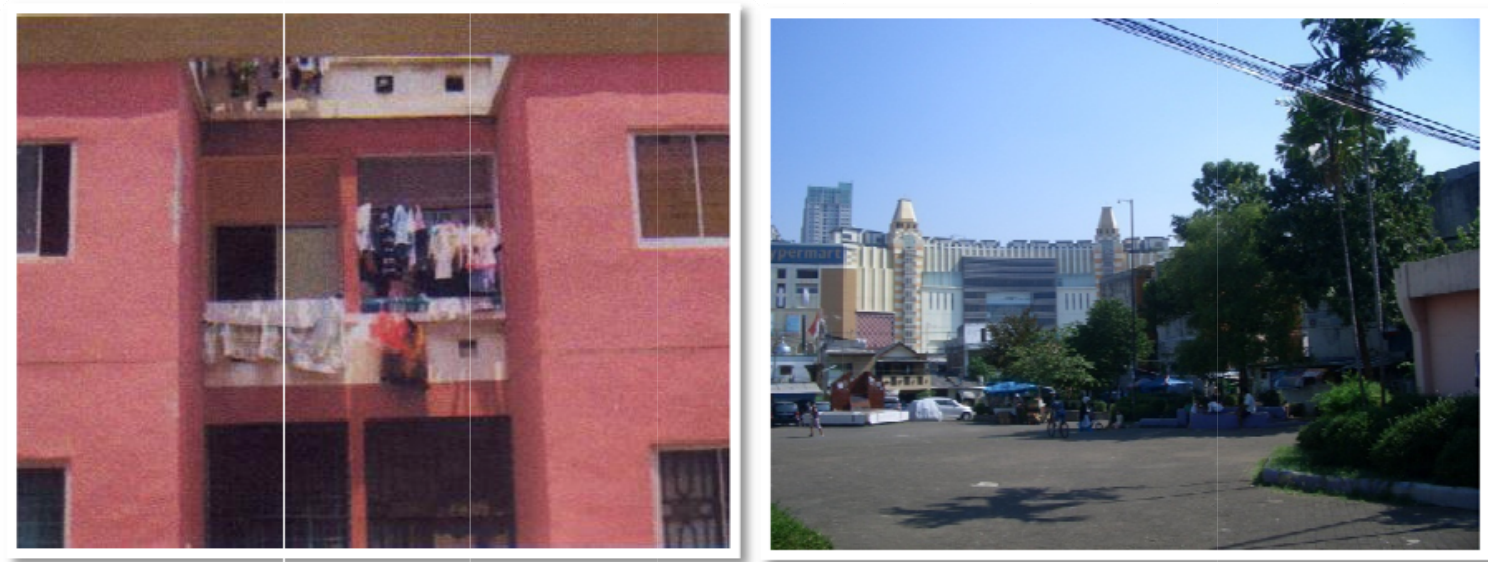

Gambar 3. Kondisi ruang di rumah susun.

(Sumber: Dokumentasi Penelitian Arsitektur Binus)

Dari beberapa sampel yang diambil, tergambar karakteristik kaum ibu penghuni rumah susun, kelompok perkumpulan wanita (ibu rumah tangga) di lingkungan rumah susun, jenis ruang terbuka yang banyak digunakan kaum ibu dan alasan-alasan kaum ibu memilih ruang terbuka sebagai tempat berkumpul. Dari Gambar 4 dan 5 dapat dilihat bahwa kaum ibu yang banyak menggunakan ruang terbuka bekerja sebagai ibu rumah tangga dan merupakan wanita dewasa yang usianya berkisar 30 50 tahun.

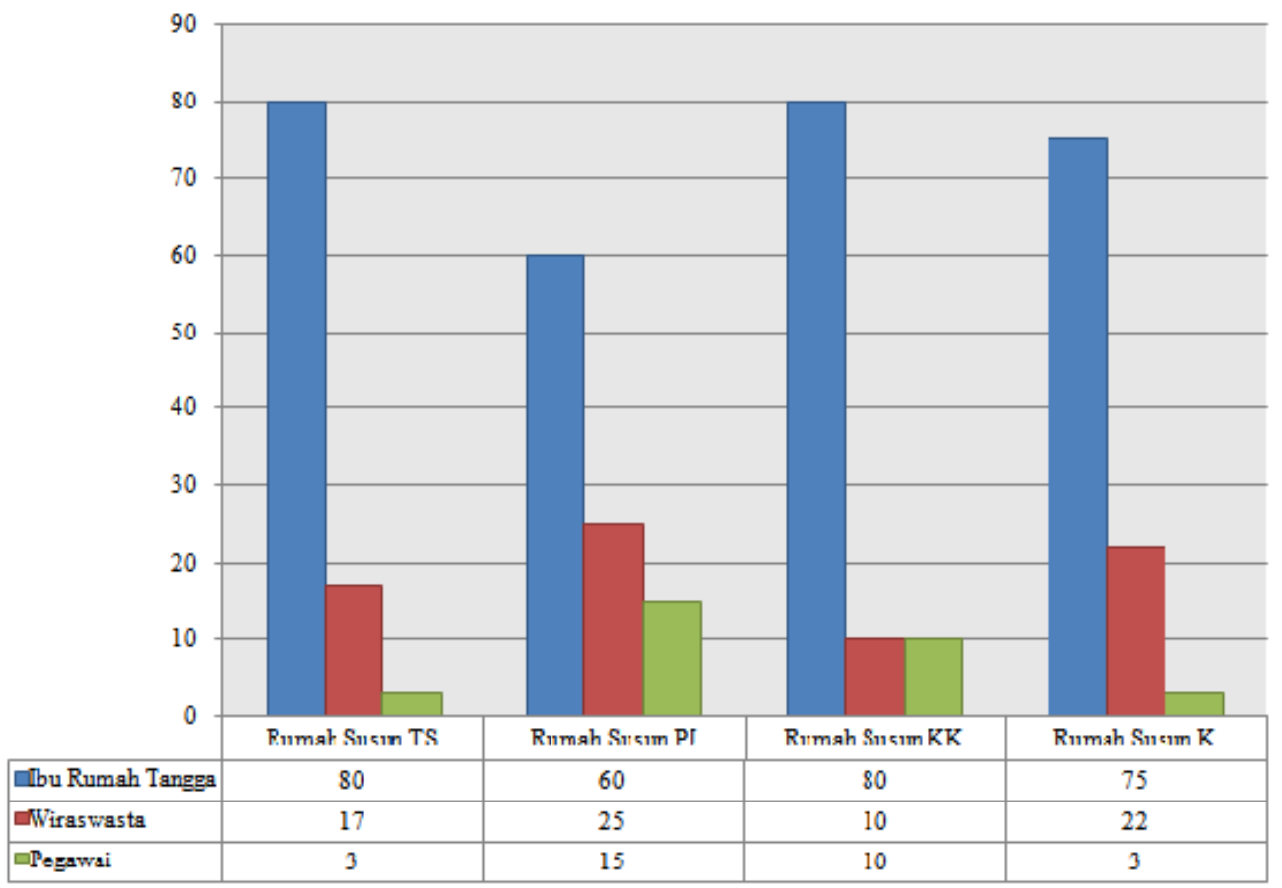

Gambar 4. Pekerjaan wanita penghuni rumah susun (N=30/rumah susun).

(Sumber: Dokumentasi Penelitian Arsitektur Binus) 


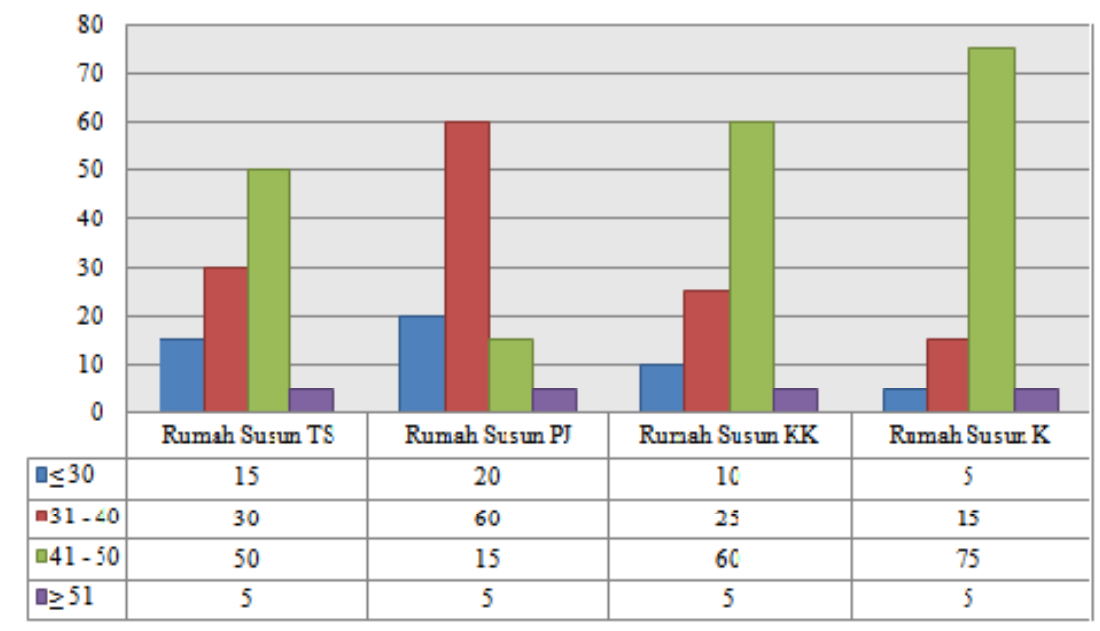

Gambar 5. Usia wanita penghuni rumah susun (N=30/rumah susun). (Sumber: Dokumentasi Penelitian Arsitektur Binus)

Pada grafik di atas, dapat diketahui bahwa usia 31 - 50 tahun merupakan usia wanita yang paling aktif dan paling banyak mengkuti kegiatan perkumpulan tersebut.

Perkumpulan atau organisasi yang dibentuk kaum ibu atau wanita sebagai penghuni rumah susun dapat dibedakan menjadi organisasi formal (perkumpulan arisan, pengajian atau kebaktian bersama) dan organisasi non formal (Gambar 6). Pada rumah susun TS, tidak ada kegiatan/perkumpulan atau organisasi formal yang diadakan, karena ibu rumah tangga penghuni rumah susun TS lebih banyak berinteraksi secara non formal yaitu dengan berbincang-bincang antara sesama penghuni.

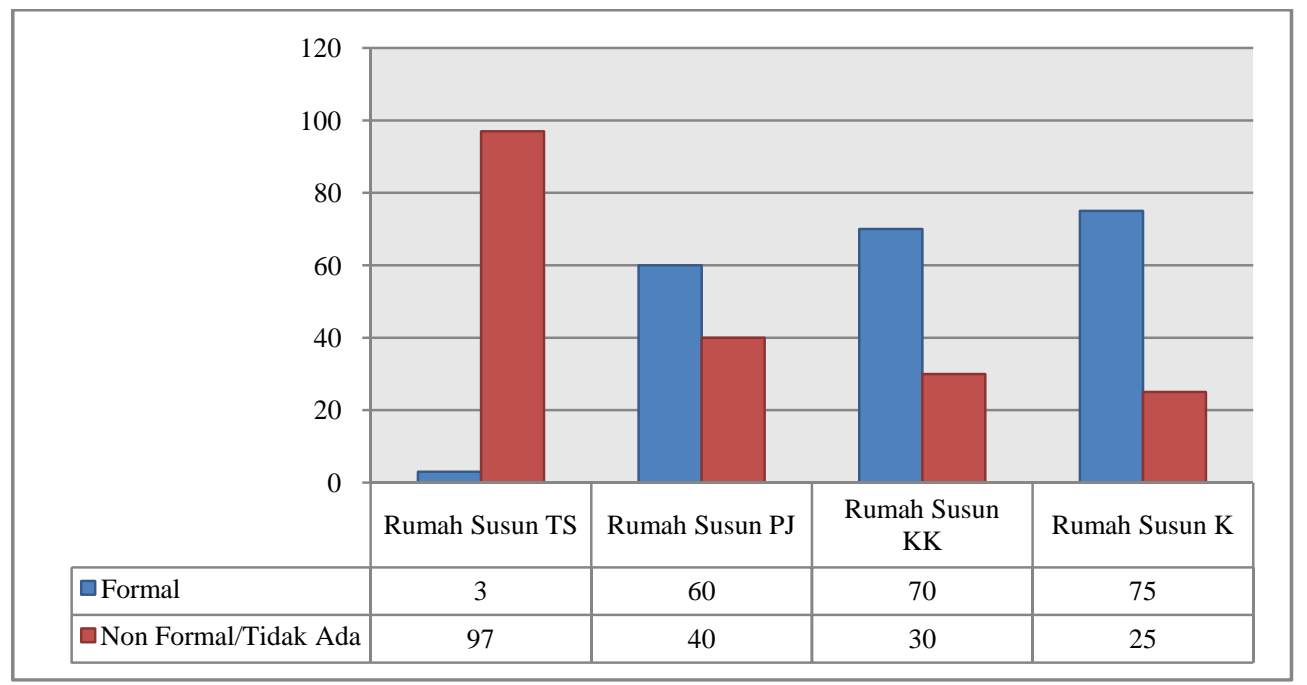

Gambar 6. Perkumpulan wanita (ibu rumah tangga) di rumah susun berdasarkan informasi penghuni rusun ( $\mathrm{N}=30 /$ rumah susun).

(Sumber: Dokumentasi Penelitian Arsitektur Binus)

Ada beberapa alasan para wanita (ibu rumah tangga) penghuni rumah susun memilih ruang terbuka untuk berkumpul dan berinteraksi, seperti tercantum pada Gambar 7. Alas an Utama adalah kemudahan pencapaian atau kedekatan dengan hunian. Jenis ruang terbuka yang dipilih oleh ibu 
rumah tangga penghuni rumah susun antara lain taman, lapangan olah raga, teras di sekitar hunian mereka seperti di koridor atau tangga rumah susun. Ada juga yang menggunakan aula atau gedung serbaguna (hall) (Gambar 8). Secara mayoritas, wanita (ibu rumah tangga) berkumpul pada pukul 17.00 - 18.00 karena pada saat itu ruang terbuka relatif sejuk atau teduh dan para ibu tersebut sedang beristirahat (Gambar 9). Mereka berkumpul di ruang terbuka untuk menghabiskan waktu.

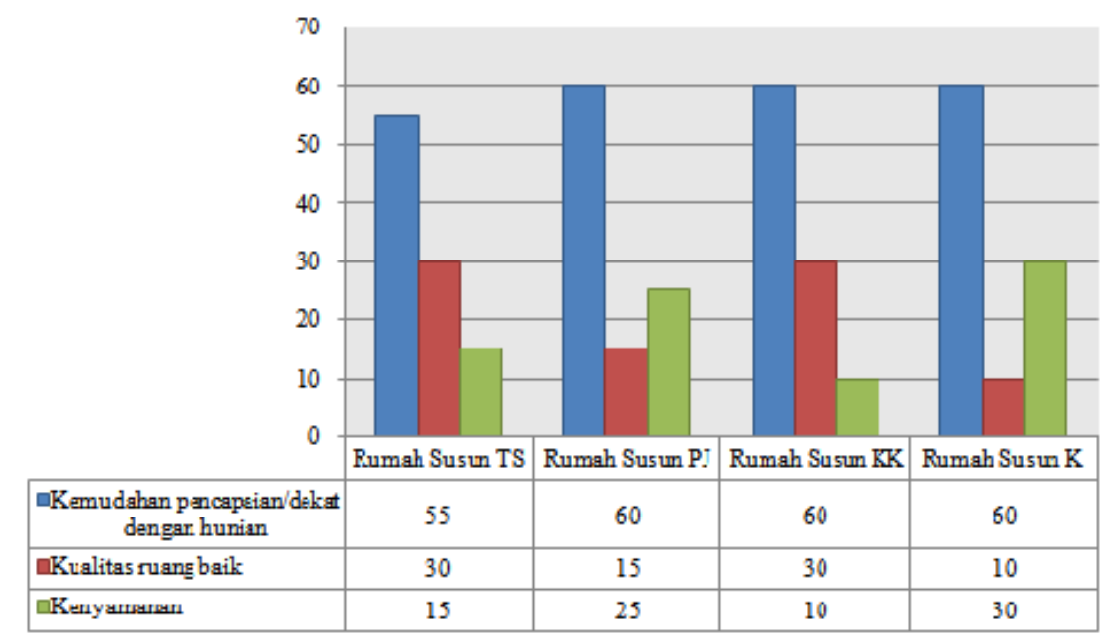

Gambar 7. Alasan pemilihan ruang terbuka di rumah susun (N=30/rumah susun).

(Sumber: Dokumentasi Penelitian Arsitektur Binus)

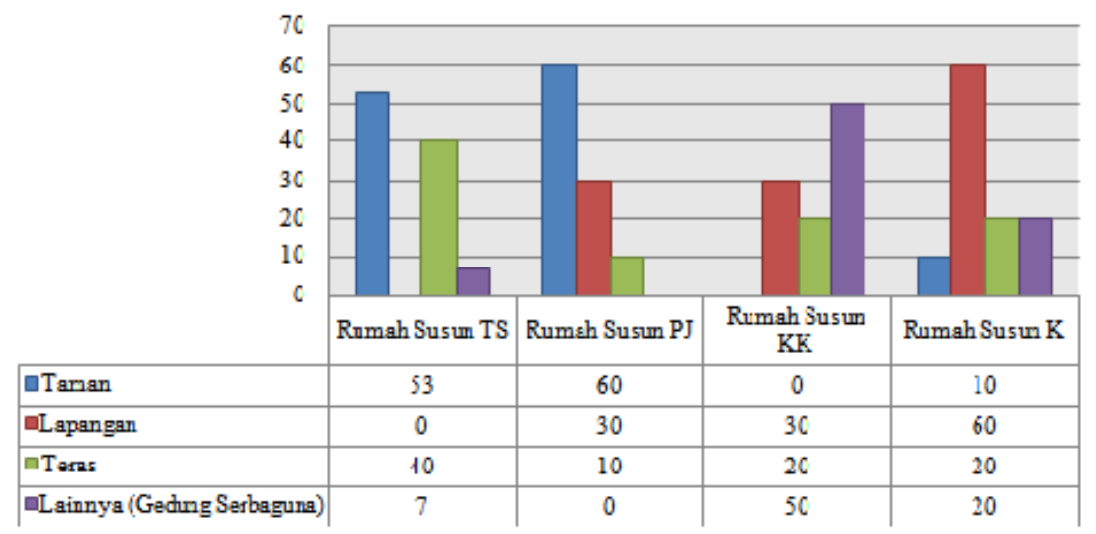

Gambar 8. Jenis ruang terbuka yang dipilih oleh kaum ibu rumah tangga di rumah susun (N=30/rumah susun). (Sumber: Dokumentasi Penelitian Arsitektur Binus)

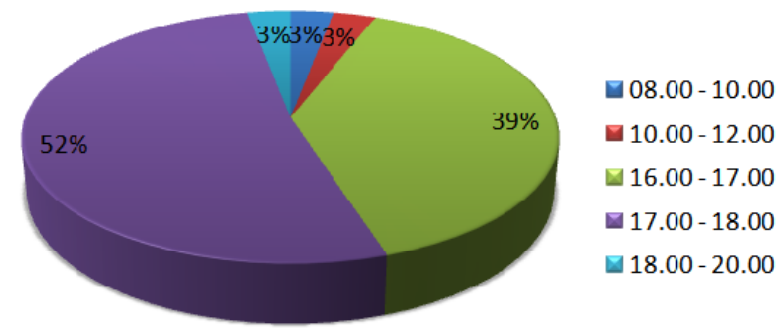

Gambar 9. Perbandingan waktu kumpul wanita (ibu rumah tangga) di rumah susun (N=30/rumah susun). (Sumber: Dokumentasi Penelitian Arsitektur Binus) 


\section{PENUTUP}

Pola pemanfaatan ruang terbuka oleh ibu rumah tangga dipengaruhi oleh: (1) faktor usia - Ibu rumah tangga memiliki kecenderungan untuk berkelompok dalam kelompok usia yang sebaya; (2) lokasi - lokasi yang sama dan bertetangga satu sama lain menciptakan sosialisasi yang baik antara para ibu rumah tangga tersebut. Ruang terbuka menjadi tempat yang strategis untuk mengakomodasi aktivitas kaum ibu rumah tangga tersebut, selain lokasinya dekat, pencapaiannya mudah dan luas ruang terbuka itu cukup memadai; (3) pekerjaan - ibu rumah tangga mempunyai urutan tertinggi. Kesamaan pekerjaan yang menyebabkan waktu-waktu kosong yang sama dan mempunyai tujuan pembicaraan yang sama. Sehingga para ibu tersebut mayoritas berkumpul pada sore hari, karena relatif teduh dan pekerjaan rumah tangga mereka umumnya sudah selesai atau mereka sedang beristirahat.

Untuk meningkatkan kualitas dari aktivitas para ibu rumah tangga, perlu dilakukan pembinaan yang terarah agar terjadi peningkatan kualitas hidup dan kesejahteraan para penghuni rumah susun tersebut. Aktivitas selama ini yang dilakukan umumnya meliputi berbincang-bincang, mengasuh anak, kegiatan rohani, dan arisan. Adanya pembinaan dan pelatihan-pelatihan yang terkoordinasi dapat meningkatkan kualitas lingkungan ruang terbuka dan kehidupan ekonomi dan sosial para penghuni rumah susun.

\section{DAFTAR PUSTAKA}

Miles, M., Hall, T., \& Borden, I. (2000). The City Cultures Readers. London: Routledge.

RI. (2011). Undang-Undang Republik Indonesia Nomor 20 Tahun 2011 tentang Rumah Susun. Jakarta: Sekertariat Negara.

Supriyatno, Budi. (2009). Manajemen Tata Ruang. Jakarta: Media Brilian. 